\title{
Structure Formation of Polycarbide-Based TiC-VC(NbC)-WC/nano WC Hard Alloys
}

\section{Cieto sakausējumu struktūru veidošanās uz polikarbīda TiC-VC(NbC)-WC/nano WC bāzes}

\author{
Liudmyla Bodrova ${ }^{1}$, Halyna $\mathrm{Kramar}^{2}$, Yaroslav Kovalchuk ${ }^{3}$, Sergiy Marynenko ${ }^{4}$, Ihor Koval ${ }^{5}$ \\ ${ }^{1-5}$ Ternopil Ivan Puluj National Technical University, Ternopil, Ukraine
}

\begin{abstract}
The process of structure formation in the alloys of the system $\mathrm{TiC}-\mathrm{VC}(\mathrm{NbC})-\mathrm{NiCr}$ with the alloying additions of the fine or nano WC, depending on the chemical composition and sintering temperature using the optical microscopy, SEM and XRD analysis, is investigated in this paper. The core/rim structure alloys were found irrespective of the amount of tungsten carbide additions. The research suggests that the adding of nano WC causes decrease in carbide grains, redistribution of the elements in the core and rim, and decrease in sintering temperature by $50-100{ }^{\circ} \mathrm{C}$.
\end{abstract}

Keywords - Alloying, core, hard alloys, inner rim, microstructure, nano additions, outer rim, titanium carbide, tungsten carbide.

\section{INTRODUCTION}

Tungsten carbide hard alloys are widely used as the instrumental material nowadays in metalworking, where they are sure to be the leaders thanks to their high cutting properties of hardness and wear resistance and as the structural material, in which their high static strength and heat resistance are realized.

During the first years of the application of tungsten carbide alloys, there arose the problem of replacing the expensive and scarce tungsten carbide by cheaper carbides, but the operation characteristics being not sufficient decreased. This resulted in the creation of new groups of hard alloys based on the system TiC-NiMo, TiC-NiCr, and $\mathrm{Cr}_{3} \mathrm{C}_{2}-\mathrm{Ni}$; however, their strength was lower than that of tungsten-cobalt alloys [1]-[2].

Further investigations testified that the application of $\mathrm{TiC}$ alloyed by other carbides of transition metals is more effective; therefore, some grades of polycarbide-based $\mathrm{TiC}$ $\mathrm{VC}$, TiC-NbC, and TiC-VC-NbC alloys were created, and some of their grades have already been applied in industry [3]-[5]. The alloys of the TiC-VC- NiCr system sufficiently combine the availability of raw materials and the mechanical and operation properties. But WC is the best alloying carbide, which, being even in small amount, affects sufficiently the strength and viscosity of alloys [6]-[9]. The correlation between the grain size of the initial materials and the properties is known to be strong; therefore, the investigation of the effects of alloying carbides on the core/rim sizes of the structure and properties of alloys was of great interest. The investigation of the effect of fine and nano alloying carbides $\mathrm{WC}$ on the properties of TiC-VC / ( VC-NbC)-NiCr alloys is of special interest, as the cutting tools made of them have revealed high operation properties [10]-[12].

Taking into account that most of the mechanical and operation properties of hard alloys are structural-sensitive, the dependence of the microstructure on the amount of alloying fine and nano tungsten carbide and the sintering temperature as the principle technological factor of the effect on the structure formation of the TiC-VC/ (VC-NbC)-NiCr-based alloys, have been investigated in the paper.

\section{MATERIALS AND METHODS}

The TiC, $\mathrm{VC}, \mathrm{NbC}$, and $\mathrm{WC}$ carbides powder with the particle size of $1-2 \mu \mathrm{m}$ and the binder metals containing the basic component of $99.8 \%$ chromium and nickel were used for the investigation. The nano-powders of tungsten carbide were produced by the "Nanostructured and Amorphous Materials, Inc." (Houston, USA).

Chemical composition of the initial materials is presented in Table I, and the chemical composition of nano WC certified by the producer is presented in Table II.

TABLE I

Chemical Composition of the Initial Materials

\begin{tabular}{|c|c|c|c|c|c|c|c|c|}
\hline \multirow[t]{2}{*}{ No. } & \multirow[t]{2}{*}{ Material } & \multicolumn{5}{|c|}{$\begin{array}{l}\text { Chemical composition, \% } \\
\text { (weight) }\end{array}$} & \multirow{2}{*}{$\begin{array}{l}\text { Stoichiometric } \\
\text { formula }\end{array}$} & \multirow[t]{2}{*}{ Particle size } \\
\hline & & $\mathrm{Me}$ & $\mathrm{C}_{\text {total }}$ & $\mathrm{C}_{\text {free }}$ & $\mathrm{O}$ & $\mathrm{S}$ & & \\
\hline 1 & $\begin{array}{l}\text { Titanium } \\
\text { carbide }\end{array}$ & 79.8 & 19.5 & 0.27 & 0.31 & $<0.003$ & $\mathrm{TiC}_{0.96}$ & $1-2 \mu \mathrm{m}$ \\
\hline 2 & $\begin{array}{l}\text { Vanadium } \\
\text { carbide }\end{array}$ & 81.5 & 17.2 & 0.9 & 0.25 & $<0.003$ & $\mathrm{VC}_{0.88}$ & $1-2 \mu \mathrm{m}$ \\
\hline 3 & $\begin{array}{l}\text { Tungsten } \\
\text { carbide }\end{array}$ & 93.6 & 5.95 & 0.1 & 0.2 & $<0.003$ & $\mathrm{WC}_{0.97}$ & $1-2 \mu \mathrm{m}$ \\
\hline 4 & Niobium & 91.2 & 8.7 & 0.15 & 0.03 & $<0.003$ & $\mathrm{NbC}_{0.74}$ & $1-2 \mu \mathrm{m}$ \\
\hline 5 & Nickel & 99.8 & 0.03 & & & $<0.003$ & & $1-2 \mu \mathrm{m}$ \\
\hline 6 & Chromium & 99.8 & 0.05 & & & $<0.003$ & & $1-2 \mu \mathrm{m}$ \\
\hline 7 & $\begin{array}{l}\text { Tungsten } \\
\text { nano-carbide }\end{array}$ & 99.5 & 6.16 & 0.03 & 0.2 & 0.001 & & $90-200 \mathrm{~nm}$ \\
\hline
\end{tabular}


The shape of nano WC particles is similar to spherical. The crystallographic lattice of nano WC is hexagonal; the specific density is $15.63 \mathrm{gr} / \mathrm{cm}^{3}$.

The alloys were obtained applying the common technology for manufacturing hard alloys, modified taking into account the peculiarities of the nano-powders application. The nano WC was added as the solution in the ethyl alcohol at the stage of alloy blending.

Alloys were sintered in a high-temperature furnace in vacuum $1.33 \times 10^{-2} \mathrm{~Pa}$ at the temperature of $1300-1450{ }^{\circ} \mathrm{C}$.

TABLE II

Chemical Composition of NANo WC BeIng Certified by the Producer (NANOSTRUCTURED AND AMORPHOUS MATERIALS, INC., HOUSTON, USA)

\begin{tabular}{|l|l|l|l|}
\hline Component & Content (\% wt) & Component & Content (\% wt) \\
\hline $\mathrm{C}_{\text {total }}$ & 6.16 & $\mathrm{~K}$ & 0.005 \\
\hline $\mathrm{C}_{\text {free }}$ & 0.03 & $\mathrm{Mn}$ & 0.0006 \\
\hline $\mathrm{O}$ & 0.20 & $\mathrm{Mo}$ & 0.003 \\
\hline $\mathrm{Al}$ & 0.0006 & $\mathrm{Na}$ & 0.0005 \\
\hline $\mathrm{As}$ & 0.001 & $\mathrm{Ni}$ & 0.0006 \\
\hline $\mathrm{Ca}$ & 0.0015 & $\mathrm{P}$ & 0.009 \\
\hline $\mathrm{Co}$ & 0.0057 & $\mathrm{~S}$ & 0.001 \\
\hline $\mathrm{Cr}$ & 0.0065 & $\mathrm{Si}$ & 0.001 \\
\hline $\mathrm{Cu}$ & 0.0006 & $\mathrm{Ti}$ & 0.001 \\
\hline $\mathrm{Fe}$ & 0.01 & $\mathrm{~V}$ & 0.0036 \\
\hline
\end{tabular}

Previous investigations [13] have demonstrated that in all alloys, the content of metal binder was $13.5 \mathrm{Ni}$ and $4.5 \mathrm{Cr}$ (\% wt).

Chemical composition of the investigated alloys is presented in Table III.

TABLE III

Chemical Composition of the Investigated Alloys Carbide Base

\begin{tabular}{|l|l|l|l|l|}
\hline \multirow{2}{*}{ No. } & \multicolumn{5}{|c|}{ Chemical composition (\% wt) } \\
\cline { 2 - 5 } & $\mathrm{TiC}$ & $\mathrm{VC}$ & $\mathrm{NbC}$ & $\mathrm{WC}$ \\
\hline 1 & 72 & 5 & - & 5 nano \\
\hline 2 & 67 & 5 & - & 10 nano \\
\hline 3 & 62 & 5 & - & 15 nano \\
\hline 4 & 72 & 5 & - & 5 \\
\hline 5 & 72 & 5 & 5 & 5 \\
\hline 6 & 67 & 5 & 5 & 10 \\
\hline 7 & 62 & 5 & 5 & 15 \\
\hline
\end{tabular}

To carry out the investigations according to the described technology, a cylinder specimen of $8 \mathrm{~mm}$ in diameter and $8 \mathrm{~mm}$ in height and the specimens of $5 \times 5 \times 35 \mathrm{~mm}$ were made.

The investigations of microstructure were carried out using the methods of XRD analysis, and optical and scanning electronic microscopy (SEM). The analysis of the alloys microstructure was performed according to the standard method of metallographic investigation of hard alloys. The microanalysis was performed using the optical microscope "Neofot-2" at a magnification of 100 and 2000, and the scanning electronic microscope "Camscan 4DV" at a magnification of up to 5000 .

Point analysis of the elements in phases and their linear distribution was performed using the semi-quantitative energy-dispersive microanalysis.

The XRD analysis was performed by using the diffractometer "DRON-4.0M" with the characteristic filtrated rays $\mathrm{Fe} \mathrm{K} \alpha$. The diffractometer survey was taken according to the Bregg-Brentano scheme. To identify the phases, the database "Pearson's Crystal Data" (structural characteristics of non-organic compounds) was used [14]. Specification of the structure parameters was performed according to the Rietveld method [15], which is based on the full-profile analysis without taking into account the integral intensity of the observed peaks taking advantage of the DBWS software [16].

\section{RESULTS OF RESEARCH AND DISCUSSION}

The investigations carried out testified that the core/rim structure of carbide grains is formed in all investigated alloys (Fig. 1). The core mostly consists of $\mathrm{TiC}$, and the rim is a complex solid solution $(\mathrm{Ti}, \mathrm{V}, \mathrm{Nb}, \mathrm{W}) \mathrm{C}$. It is known that the highest mechanical properties of the alloys correspond to the structural state when the thickness of the rim and core does not exceed $3 \mu \mathrm{m}$ [17]. At larger core/rim sizes, the hardness and strength of alloys decrease.

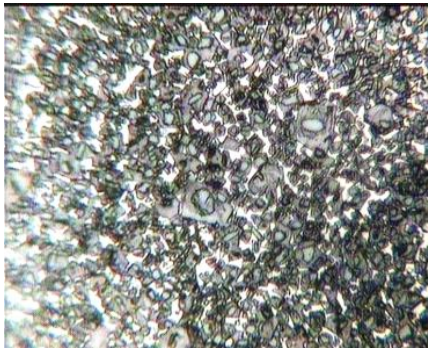

a)

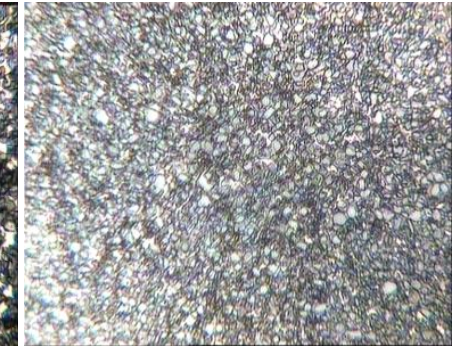

b)
Fig. 1. Microstructure of alloys with additions of $5 \%$ (wt) fine (a) and nano $\mathrm{WC}(\mathrm{b})$; sintering temperature $-1400{ }^{\circ} \mathrm{C}$.

The alloys with nano WC additions form a fine structure with the average grain $\mathrm{d}=0.76 \mu \mathrm{m}$ already at the sintering temperature of $1350{ }^{\circ} \mathrm{C}$. At the same time, for the alloys with fine $\mathrm{WC}$, the structure with the average grain $\mathrm{d}=1.2 \mu \mathrm{m}$ was formed only at $1450{ }^{\circ} \mathrm{C}$ (Fig. 2).

The adding of alloying additions WC causes the division of carbide rim into two parts: enriched (inner rim), and nonenriched (outer rim) of tungsten. Besides, the core/rim structure and the sizes of its sublayers (enriched and nonenriched by the tungsten) are changed.

In the structures of investigated alloys, the following structure components were found: $\operatorname{binder}(\beta)$, and three types of carbide grain: core $(\alpha)$ - inner $\operatorname{rim}\left(\gamma^{\prime}\right)$ - outer rim $(\gamma)$; core $(\alpha)-\operatorname{rim}(\gamma)$; homogeneous carbide grains ( $\left.\alpha^{\prime}\right)$ (Fig. 3).

The core is identified as the phase $\alpha$ containing typically the particles of the initial $\mathrm{TiC}$ being not changed under sintering. Besides titanium carbide, small amounts of $\mathrm{V}, \mathrm{Nb}, \mathrm{Cr}$, and $\mathrm{W}$ are dissolved in it, which conform to the data of quantitative elements distribution in the structure components (Fig. 4). 


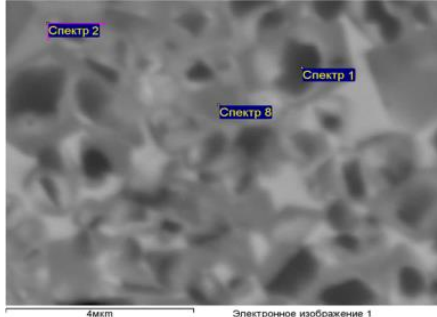

a)

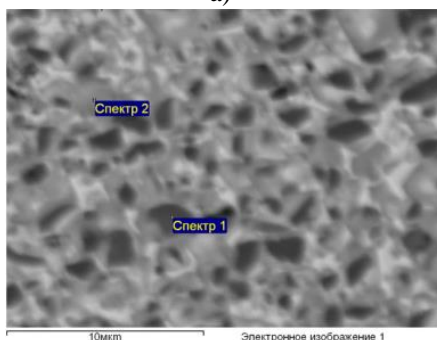

c)

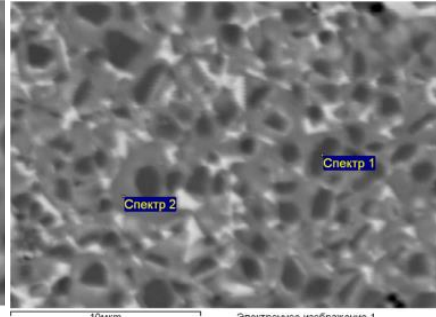

b)

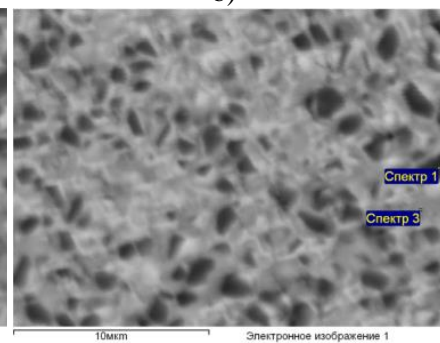

d)
Fig. 2. Microstructure of alloys with additions of $5 \%$ (wt) fine (a) and $5 \%$ (b), $10 \%$ (c), $15 \%$ (d) (wt) nano WC; sintering temperatures $-1450{ }^{\circ} \mathrm{C}(\mathrm{a})$ and $1350{ }^{\circ} \mathrm{C}(\mathrm{b}, \mathrm{c}, \mathrm{d})$.

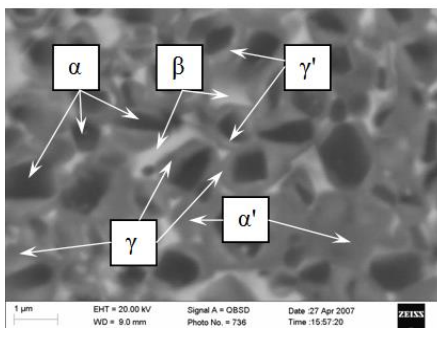

a)

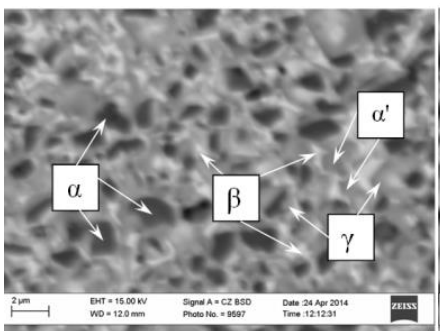

c)

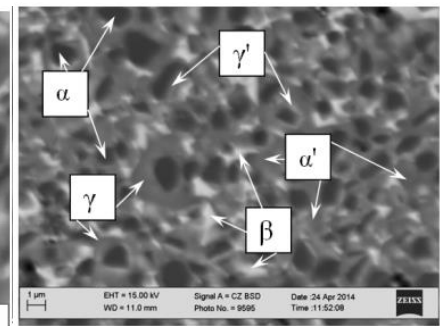

b)

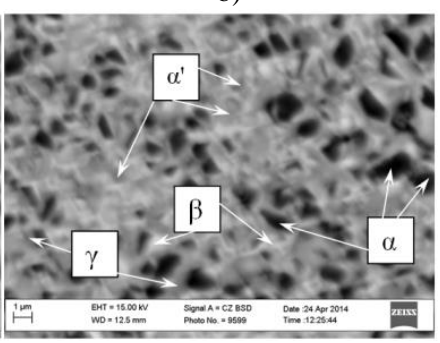

d)

Fig. 3. Microstructure of alloys with additions of $5 \%$ (wt) fine (a) and $5 \%$ (b), $10 \%$ (c), $15 \%$ (d) (wt) nano WC

with typical elements of structure: core $(\alpha)$, inner $\operatorname{rim}\left(\gamma^{\prime}\right)$, outer $\operatorname{rim}(\gamma)$, homogeneous carbide grains $\left(\alpha^{\prime}\right)$, and binder $(\beta)$.

The inner rim $\gamma^{\prime}$ is a solid solution of the TiC-based metal alloying carbides and the binder metal - nickel and chromium. The inner rim is saturated by the tungsten and is like the barrier for the diffusion processes. But in the alloys with the 10 and $15 \%$ wt of nano WC, the inner rim is not available or almost not noticed.

The outer rim $\gamma$ (or the rim for the alloys with 10 and $15 \%$ wt of nano WC) is a TiC-based solid solution with a smaller amount of alloying carbide metals, $\mathrm{W}$ in particular, which contains $\mathrm{Ni}$ and $\mathrm{Cr}$ as well.

The homogeneous carbide grains $\alpha^{\prime}$ are of sufficiently smaller sizes $(0.1-0.3 \mu \mathrm{m})$ and of the highest titanium content at a small amount of the binder metal.

The binder $\beta$ is indentified as the nickel-based solid solution of titanium, vanadium, niobium, tungsten, and chromium.
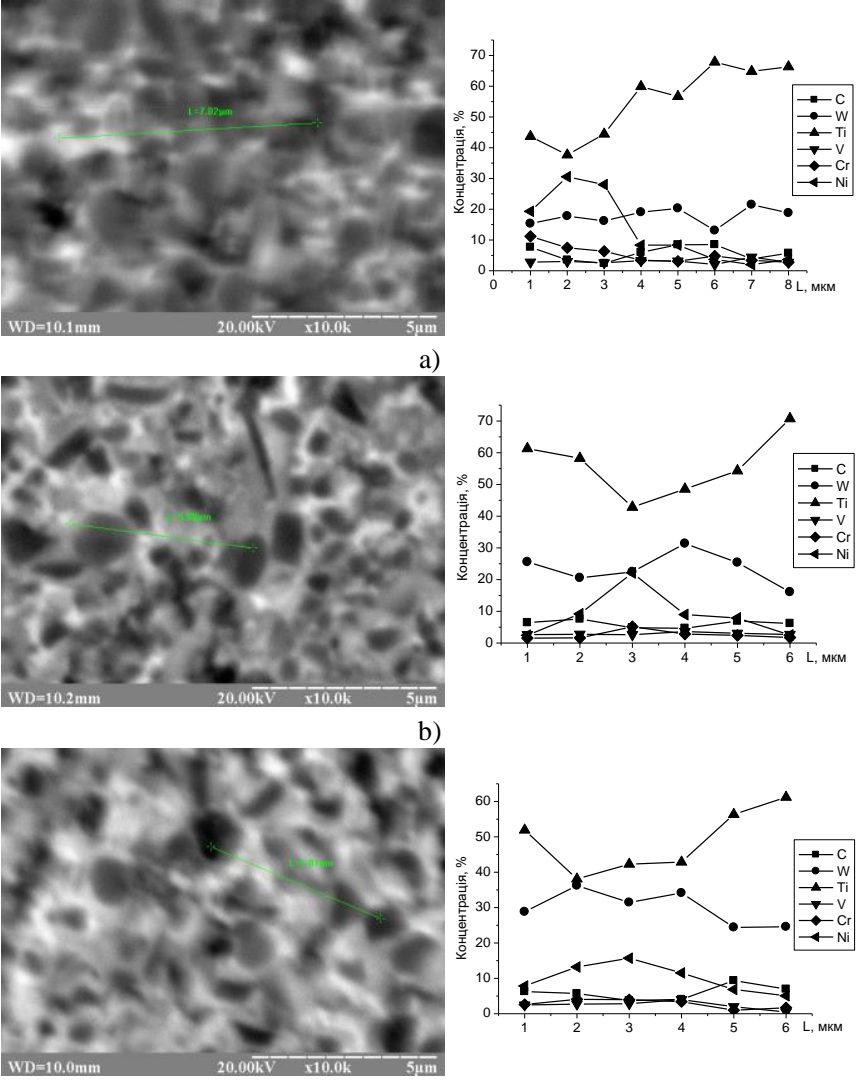

c)

Fig. 4. Microstructure and elements distribution along the line of alloys with additions of $5 \%$ (a), $10 \%$ (b), and $15 \%$ (c) (wt) nano WC sintering temperature $-1300{ }^{\circ} \mathrm{C}$.

Using the semi-quantitative energy-dispersive microanalysis, the chemical composition of the alloys structure elements was found: the core (Fig. 5) (spectrum 1 in Fig. 2), rims (Fig. 6) (spectrums 2, 3, and 8 in Fig. 2), and the binder (Fig. 7).
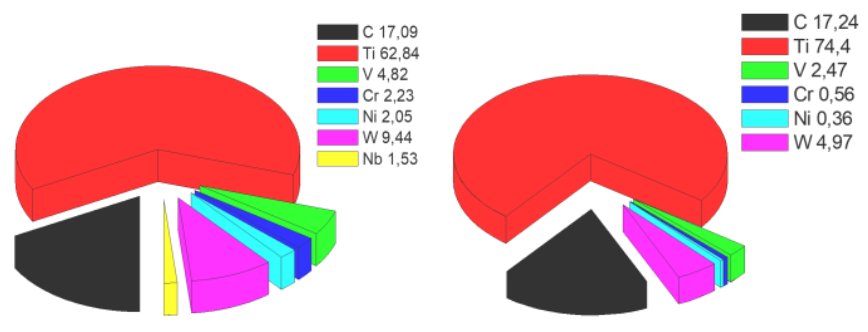

a)

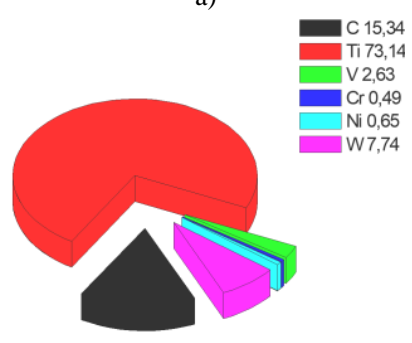

c)

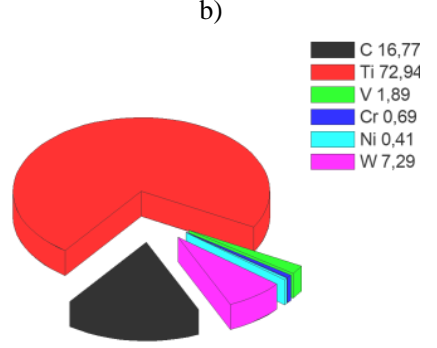

d)
Fig. 5. Chemical composition in the spectrum 1 of the core being alloyed by the $5 \%$ (wt) fine WC (a), $5 \%$ (b), $10 \%$ (c), and $15 \%$ (d) (wt) nano WC; sintering temperature $-1350{ }^{\circ} \mathrm{C}$. 

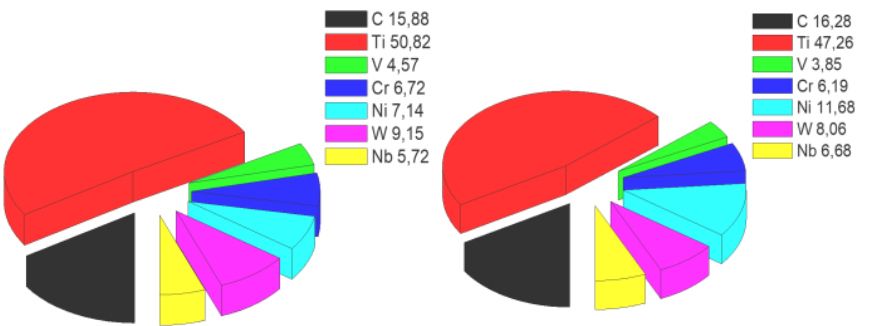

a)
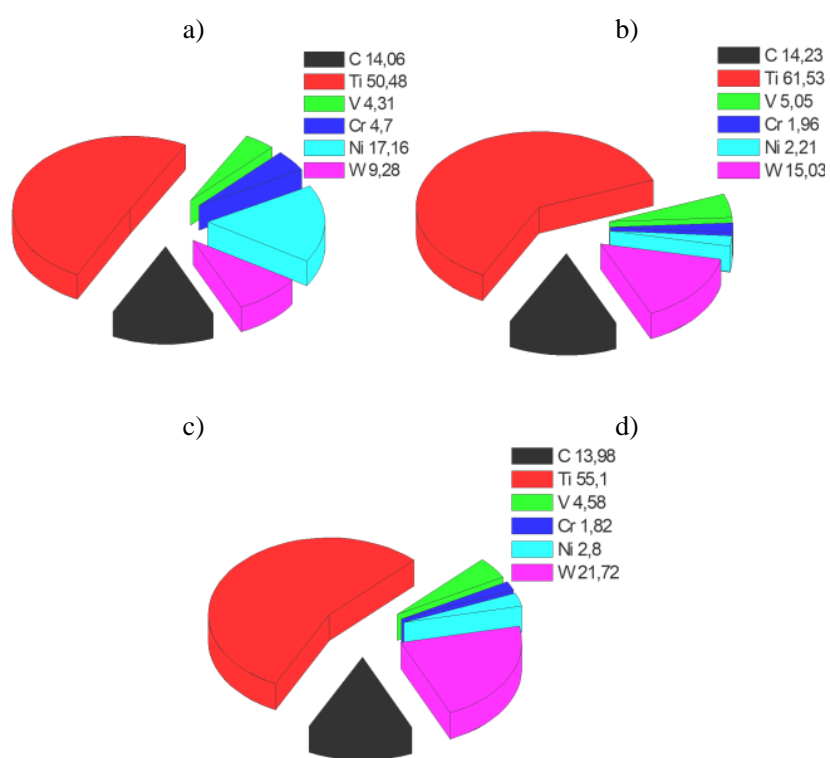

d)

e)

Fig. 6. Chemical composition in the spectrums 2, 3, and 8 of the outer rim

(a) and inner rim (b) being alloyed by $5 \%$ (wt) fine WC, and the rim being alloyed by $5 \%$ (c), $10 \%$ (d), and $15 \%$ (e) (wt) nano WC; sintering temperature $-1350{ }^{\circ} \mathrm{C}$.

Despite the available inner rim in the alloys alloyed by the $5 \%$ nano WC (wt), we failed to determine its chemical composition, as the distribution ability of the microscope was bigger than the size of its rim.

When the amount of nano WC is increased, the percentage of $\mathrm{W}$ in the core increases from 4.97 to $7.74 \%$ (wt), Ti being decreased from 74.4 to $72.94 \%$ (wt). In the rim, the percentage of $\mathrm{W}$ increases from 9.28 to 21.72 and Cr decreases from 4.7 to $1.82 \%$ (wt).

The results of the semi-quantitative energy-dispersive microanalysis showed that the data on the element distribution testified that the content of tungsten on the outer rim of the solid solution rim is equal to $6.65 \%(\mathrm{wt})$, and on the inner rim, adjusting to the carbide core, $\mathrm{Ti}$ is $17.85 \%$ (wt).

The adding of the WC alloying additions causes some balance of the tungsten concentration in the complex solid solution of carbides and an increased homogeneity within both the rim and the core.

Thus, it is shown that the adding of the WC alloying additions in the amount of $10 \%$ (wt) and more increases the balance of the tungsten concentration in the rim of the complex solid solution of carbides.

\section{$\square$ 5\% нано-WC $\square 10 \%$ нано-WC $\square 15 \%$ нано-WC}

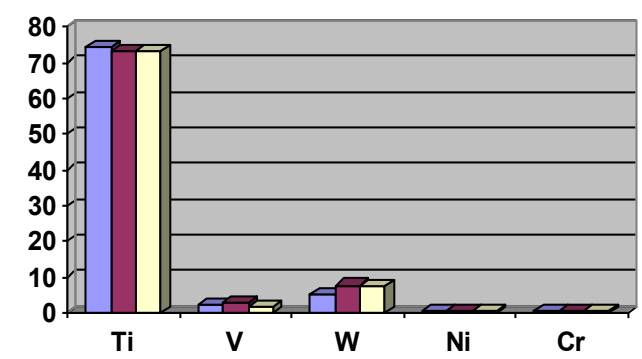

a)

\section{$\square$ 5\% нано-WC $\square 10 \%$ нано-WC $\square$ 15\% нано-WC}

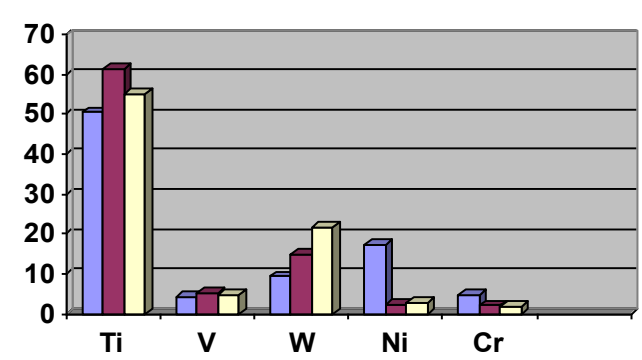

b)

\section{$\square$ \% нано-WC $\square 10 \%$ нано-WC $\square 15 \%$ нано-WC}

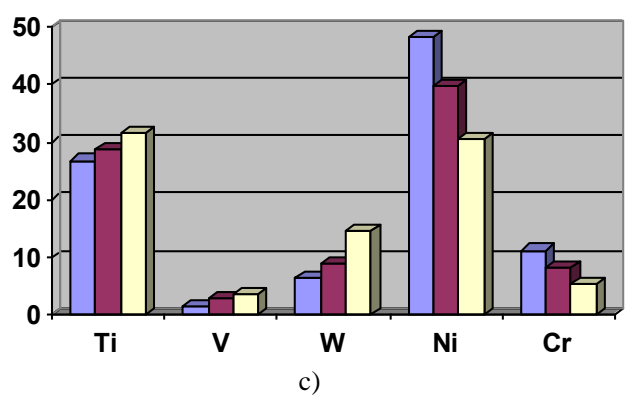

Fig. 7. Chemical composition of the alloys structural components being alloyed by nano WC: $\mathrm{a}$ - core; $\mathrm{b}$ - rim; $\mathrm{c}$ - binder; sintering temperature $-1350{ }^{\circ} \mathrm{C}$.

Using the XRD analysis (Fig. 8), the main phases of the investigated alloys were determined: in the alloys being alloyed by nano WC, irrespective of its content and sintering temperature, the main phases are the solid solution $(\mathrm{Ti}, \mathrm{V}, \mathrm{Nb}$, and $\mathrm{W}) \mathrm{C}, \mathrm{Ni}_{0.75} \mathrm{Cr}_{0.25}$ and $\mathrm{Cr}$ with the cubic structures of $\mathrm{NaCl}, \mathrm{Cu}$ and $\mathrm{W}$ (the Pearson symbol c12; space group Im-3m), correspondingly, and in the alloys being alloyed by the fine $\mathrm{WC}-(\mathrm{Ti}, \mathrm{V}, \mathrm{Nb}$, and $\mathrm{W}) \mathrm{C}, \mathrm{Ni}_{0.5} \mathrm{Cr}_{0.5}, \mathrm{Cr}$ and the tracks of $\mathrm{Cr}_{3} \mathrm{C}_{2}$ and $\mathrm{Cr}_{23} \mathrm{C}_{6}$. It should be noted that the composition of the phase $(\mathrm{Ni}, \mathrm{Cr})$ in this specimen is described by the formula $\mathrm{Ni}_{0.5} \mathrm{Cr}_{0.5}$, which is testified by the lattice parameters $(a=0.36012(6) \mathrm{nm})$, which differ greatly from the parameter of the phase unit cell $\mathrm{Ni}_{0.75} \mathrm{Cr}_{0.25}$ $(a=0.35807(9)-0.35632(5) \mathrm{nm})$.

The increase of the $\mathrm{W}$ dissolution in the TiC phase testifier well the change of the unit cell. In the solution with $5 \%$ nano $\mathrm{WC}(\mathrm{wt})$, the lattice parameter equals $a=0.43148(7) \mathrm{nm}$. 


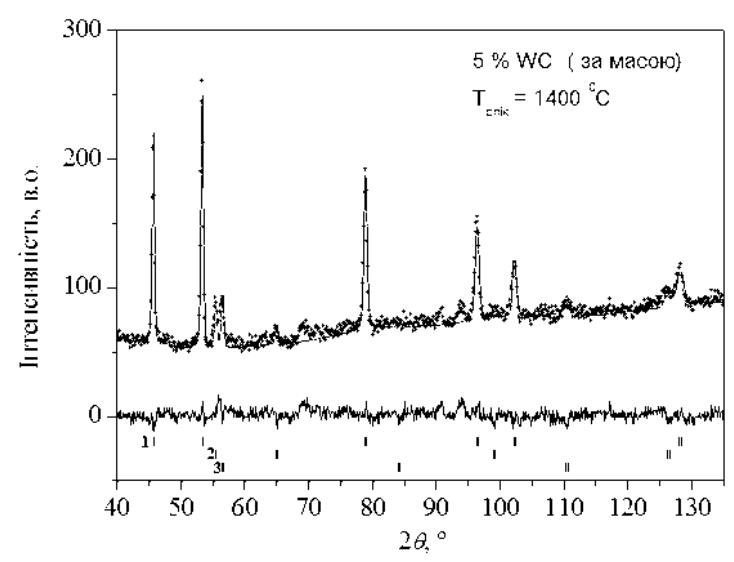

a)

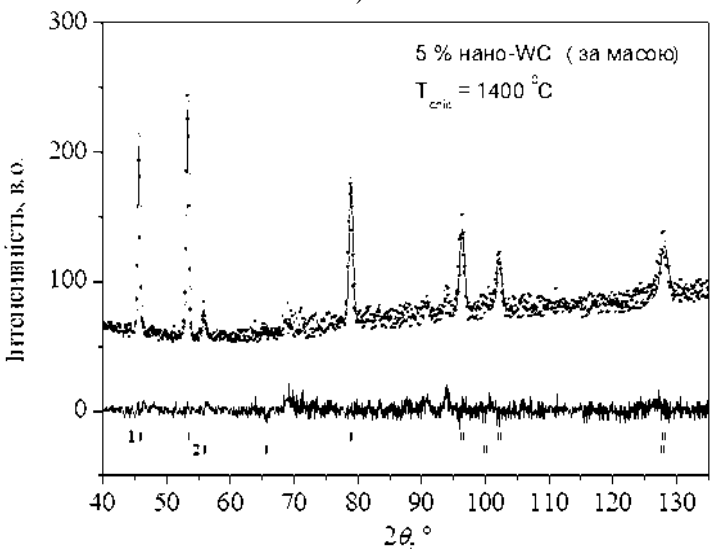

b)

Fig. 8. Experimental (dots), calculation (line), and difference patterns of the alloys with $5 \%$ (wt) fine WC (a) and nano WC (b).

When the $\mathrm{W}$ dissolution is increased, i. e., when some Ti atoms are replaced by $\mathrm{W}$ atoms, the lattice parameter decreases to $a=0.42985(6) \mathrm{nm}$ for the alloy with $10 \%$ nano $\mathrm{WC}$ and to $a=0.42978(6) \mathrm{nm}$ for the alloy with $5 \%$ nano $\mathrm{WC}$, which conformes to the atom radius of $\mathrm{Ti}\left(r_{\mathrm{a}}=0.147 \mathrm{~nm}\right)$ and $\mathrm{W}\left(r_{\mathrm{a}}=0.139 \mathrm{~nm}\right)$.

\section{CONCLUSION}

The investigations testified that all alloys, both with the fine and nano additions of the alloying WC, are of the core/rim structure. It was determined that the rim for the alloys being alloyed by the fine $\mathrm{WC}$ and $5 \%$ (wt) nano WC, consists of the inner and outer rims. The increase in the amount of nano WC results in the homogenization of the rim and in the formation of a larger amount of fine homogenous carbide grains.

The phase composition of alloys with fine $\mathrm{WC}$ is specified by the available $\mathrm{Cr}_{3} \mathrm{C}_{2}$ and $\mathrm{Cr}_{23} \mathrm{C}_{6}$ tracks and the ratio of metals binder.

The change in sintering temperature from $1300^{\circ} \mathrm{C}$ to $1450{ }^{\circ} \mathrm{C}$ results in the formation of the fine structure of alloys at $1350{ }^{\circ} \mathrm{C}$ for the alloys with the nano $\mathrm{WC}$, and at $1450{ }^{\circ} \mathrm{C}$ for the alloys being alloyed by the fine WC. The decrease in sintering temperature by $50-100{ }^{\circ} \mathrm{C}$ allows decreasing the power expenditures of the manufacturing process.

\section{REFERENCES}

[1] V. I. Tretyakov, "To the history of hard alloys," Instrumental Word, no 3, pp. 15-17, 1998.

[2] V. S. Panov and A. M. Chuvilin, Technology and properties of sintered hard alloys and their products. M.: MISiS, 2001, $428 \mathrm{p}$.

[3] L. G. Bodrova and G. M. Kramar, "The microstructure of titanium and vanadium carbide based hard alloys," in Advances in Hard Materials Production Proc. of European Conf., Turin, Italy, 1999. pp. 269-276.

[4] L. Bodrova, V. Lazaryuk and H. Kramar, "Properties and composition of the TiC-NbC based cemented carbides," in Proc. of the Powder Metallurgy World Congr., Granada, Spain, 1998, pp. 105-109.

[5] C. J. Choi, B. G. Moon and W. W. Park, "Synthesis of TiC-Ni(-Mo) Cermet via Mechanical alloying," in Proc. of 1998 Powder Metallurgy World Congr. and Exhibition, Granada, Spain, 1988, vol. 4, pp. 45-50.

[6] Ye. S. Gevorkyan, Yu. G.Gutsalenko and M. M. Prokopiv, "Effect of nanoscale particles on the properties of tungsten monocarbide carbide cutting materials," Sat scientific works Ukrainian Research Institute of Refractories named after A.S. Berezhnoy, JSC, Harkiv: Caravella, 2010, no 110, pp. 313-318.

[7] S.Yu. Marinenko, L.G. Bodrova, G.M. Kramar and V.V. Lazaryuk, "Special features of structure formation in polycarbide based hard alloys," J. of Superhard Materials, vol. 31, no. 2, pp. 89-96, Apr. 2009. https://doi.org/10.3103/s1063457609020051.

[8] Ji Xiong, Zhixing Guo, Baoluo Shen and Ding Cao, "The effect of $\mathrm{Mo}_{2} \mathrm{C}$, WC and $\mathrm{TaC}$ on the microstructure and properties of ultra-fine $\mathrm{TiC}_{0.7} \mathrm{~N}_{0.3}$ cerme," Materials \& Design, vol. 28, no 5, pp. 1689-1694, Jan. 2007. https://doi.org/10.1016/j.matdes.2006.03.005.

[9] Yan Li, Ning Liu, Xiaobo Zhang and Chunlan Rong, "Effect of WC content on the microstructure and mechanical properties of $(\mathrm{Ti}, \mathrm{W})(\mathrm{C}, \mathrm{N})-\mathrm{Co}$ cermets," Int. J. of Refractory Metals \& Hard Materials, vol. 26, no 1, pp. 33-40, Jan 2008. https://doi.org/10.1016/j.ijrmhm.2007.01.003.

[10] I.V. Koval, L.G. Bodrova, H.M. Kramar, S.Yu. Marynenko and Ya.O. Kovalchuk, "Investigation of the polycarbide hard alloys fracture nature under thermocyclic loadings," Intercollegiate collection "Scientific notes", no 59, pp. 144-148, 2017.

[11] S.Yu. Marynenko, H.M. Kramar and L.G. Bodrova, "Tribotechnical properties of hard alloys on a polycarbide base," in Collection of scientific works of the XI Intern. Conf. "Tribology and Reliability", St. Petersburg: PSTU, 2011, pp. 150-156.

[12] S.Yu. Marynenko, H.M. Kramar, L.G. Bodrova et al., "Features of wear of hard alloys ( $\mathrm{Ti}, \mathrm{V}, \mathrm{Nb}, \mathrm{W}) \mathrm{C}-\mathrm{NiCr}$ in the process of cutting," Announcer TSTU, vol. 14, no 4, pp. 27-32, 2009.

[13] L.G. Bodrova, H.M. Kramar, S.Yu. Marynenko et al., "New tungsten free hard alloys with higher exploitation properties," Instrumental word, vol. 1, no 2, pp. 54-56, 2011.

[14] P. Villars and K. Cenzual Eds., "Pearson's Crystal Data," in Crystal Structure Database for Inorganic Compounds, Release 2015/16, ASM International, Materials Park, Ohio, USA.

[15] R.A. Young, Eds., The Rietveld Method, Oxford, United Kingdom: Oxford University Press, 1995.

[16] R.A. Young, A. Sakthivel, T.S. Moss and C.O. Paiva-Santos, "DBWS-9411 - an upgrade of the DBWS*.* programs for Rietveld refinement with PC and mainframe computers," J. of Applied Crystallography, vol. 28, no 3, pp. 366-367, Jun. 1995, https://doi.org/10.1107/s0021889895002160.

[17] V. A. Zhilyaev and E. I. Patrakov, "Influence of the methods of obtaining TiC-Ni-Mo alloy on the peculiarities of the formation of its composition and microstructure," Powder Metallurgy and Metal Ceramics, vol. 28, no 8, pp. 626-632, Aug. 1989, https://doi.org/10.1007/bf00794579. 


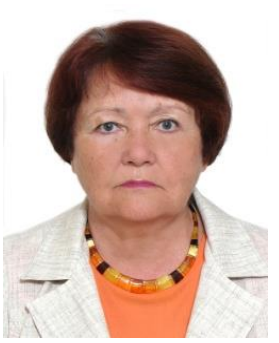

Liudmyla Bodrova received the Ph.D. degree in engineering from the Institute for Problems in Materials Science, Kyiv, Ukraine, in 1975. The theme of the thesis was "Research of conditions for obtaining the structure and properties of higher molybdenum and tungsten borides and their alloys". In 1969, she graduated from Kyiv Polytechnical Institute, with a speciality in powder metallurgy. She is currently a Professor at the Department of Structural Mechanics of Ternopil Ivan Puluj National Technical University, Ukraine.

Her major areas of scientific activity are: titanium carbide and policarbidebased hard alloys technology, properties, and application; and the use of nanomaterials and nanotechnologies in the production of hard alloys. She is the author of more than 170 scientific papers, published in international and Ukrainian scientific journals. She has participated in many international and European conferences of materials science and powder metallurgy. She is the owner of 10 patents and patents for inventions in new brands of carbide-based alloys and methods for their production. L. Bodrova is the Scientific Supervisor of Hard Alloys Laboratory of Ternopil Ivan Puluj National Technical University, and the Head of a number of successful scientific projects funded by the Ministry of Education and Science of Ukraine.

E-mail: 1_bodrova@lycos.com

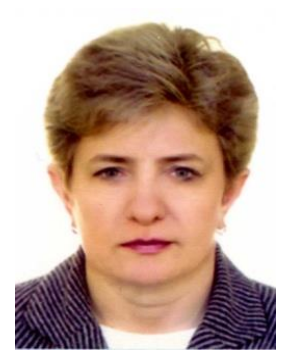

Halyna Kramar received the Ph.D. degree in engineering from V. Bakul Institute for Superhard Materials NAS of Ukraine in 1993. The theme of the thesis was "Research of tungsten free hard alloys on the basis of cutting and stamping tools". In 1984, she graduated from the State University "Lvivs'ka Politekhnica", Ukraine, with the speciality of a mechanical engineer in mechanical engineering. She is the Vice-Head of the Department of Structural Mechanics of Ternopil Ivan Puluj National Technical University, Ukraine, and the Academic Secretary of the Academic Council of University.

Her major areas of scientific activity are: powder metallurgy, titanium and polycarbide-based hard alloys and their application; theory and technology sintering; nanotechnology and nanomaterials.

From 1994 to 1996, she has been with the Cabinet of the Ministers of Ukraine for the scholarships for young scientists. She has participated in the World and European Congresses of powder metallurgy (Spain, 1998; Italy, 1999 and 2010; Czech Republic, 2005; Austria, 2004 and 2013; France, 2000, 2007, 2011, and 2015).

H. Kramar is the author of more than 130 scientific papers and academic publications, and five patents

E-mail: vr@tu.edu.te.ua

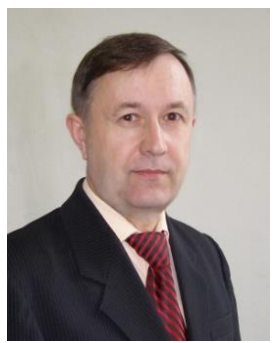

Yaroslav Kovalchuk received the $\mathrm{Ph} . \mathrm{D}$. degree in engineering from Ternopil Ivan Puluj State Technical University, Ukraine, in 1999. The theme of the thesis was "Influence of the previous plastic deformation on the cyclic crack resistance of an aluminum alloy". In 1980, he graduated from the State University "Lvivs'ka Politekhnica", Ukraine, with the speciality of a mechanical engineer in mechanical engineering. He is currently the Head of Structural Mechanics Department of Ternopil Ivan Puluj National Technical University, Ukraine.

His major areas of scientific activity are: fracture mechanics, and the investigations of the operation properties of hard alloys. Y. Kovalchuk is the Executive Director of the Scientific Projects funded by the Ministry of Education and Science of Ukraine, and the Scientific Supervisor of the University Laboratory of Physical-Mechanical and Operational Properties of Structural Materials.

E-mail: yarkv@i.ua

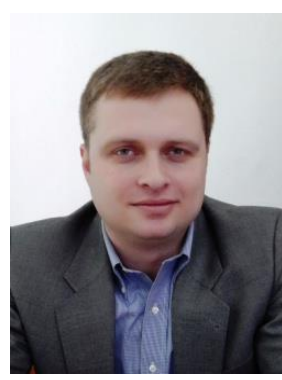

Sergiy Marynenko received the Ph.D. degree in engineering from Kherson State Maritime Academy, Ukraine, in 2013. The theme of the thesis was "Regularities of the structure and properties formation of the tool alloys based on the alloyed titanium carbide". In 2003, he graduated from Ternopil Ivan Puluj State Technical University, Ukraine, with the speciality of a mechanical engineer in the technologies and equipment of welding production. Currently, he is an Associate Professor at the Technologies and Equipment of Welding Production Department of Ternopil Ivan Puluj National Technical University.

His major areas of scientific activity are: hard alloys based on titanium carbide technology, their properties and applications, welding technology, welding processes, the strength and durability of welded structures. $\mathrm{S}$. Marynenko is the author of more than 50 scientific papers.

E-mail: west-income@i.ua

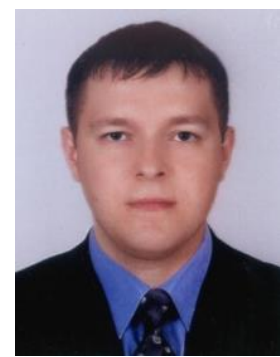

Ihor Koval received the Ph.D. degree in engineering from Lutsk National Technical University, Ukraine, in 2016. The theme of the thesis was "Influence of nano tungsten carbide on microstructure and properties of titanium carbidebased hard alloys". In 2006, he graduated from Ternopil Ivan Puluj State Technical University, Ukraine, with the speciality of a mechanical engineer in mechanical engineering. In 2007, he earned the Master's degree in metal cutting machine and systems from Ternopil Ivan Puluj State Technical University. Since 2010, he is a Physics Teacher in the speciality of pedagogy and methodology of secondary education, physics, at Ternopil Volodymyr Hnatiuk National Pedagogical University, Ukraine, and the Senior Lecturer at the Department of Structural Mechanics of Ternopil Ivan Puluj National Technical University.

His major areas of scientific activity are: hard alloys, their properties and application, cutting instruments and devices, structural materials, mechanics, physics, nanomaterials and nanotechnologies. I. Koval is the author of more than 30 scientific papers.

E-mail: goracio@i.ua

Cieto sakausējumu struktūru veidošanās uz polikarbīda TiC-VC(NbC)-WC/nano WC bāzes Liudmyla Bodrova ${ }^{1}$, Halyna Kramar ${ }^{2}$, Yaroslav Kovalchuk $^{3}$, Sergiy Marynenko ${ }^{4}$, Ihor Koval ${ }^{5}$ 1-5 Ternopiles Valsts Ivana Puluja Tehniskā universitäte, Ternopile, Ukraina

Tika pētīts struktūru veidošanas process sakausējumos TiC-VC(NbC)-NiCr ar smalku vai nano WC sakausējuma papildinājumiem atkarībā no k̄īmiskā sastāva un saḳepināšanas temperatūras, izmantojot optisko mikroskopiju, SEM un XRD analīzi. Centru/aptvērumu struktūras sakausējumi tika konstatēti neatkarīgi no volframa karbīda piedevu daudzuma. Pētījums liecina, ka nano WC pievienošana samazina karbīda graudus, elementu pārdali centros un aptvērumos, kā arī notiek saķepināšanās temperatūras samazināšanās par $50-100^{\circ} \mathrm{C}$.

Atslēgas vārdi - Sakausējums, centri, cietie sakausējumi, iekšējais aptvērums, mikrostruktūra, nano papildinājumi, ārējais aptvērums, titāna karbīds, volframa karbīds. 